\title{
A Proposed Evaluation Framework for School Management Information Systems (SMIS) in secondary schools
}

\author{
Bernard Okeyo Amollo *, Dr. Joshua Agola **, Prof. Antony Rodrigues **** \\ * Jaramogi Oginga Odinga University of Science and Technology-Kenya \\ ** Jaramogi Oginga Odinga University of Science and Technology-Kenya \\ *** Jaramogi Oginga Odinga University of Science and Technology-Kenya
}

DOI: 10.29322/IJSRP.12.01.2022.p12164

http://dx.doi.org/10.29322/IJSRP.12.01.2022.p12164

\begin{abstract}
Many organizations decide to implement information systems in order to improve the effectiveness and efficiency of their organizations, however, lack of awareness of numerous and varied challenging issues surrounding the implementation process could be problematic for the whole process. In particular lack of key success issues seems to be a serious obstacle for the management information system implementation process.

The use and application of ICT is on the rise impacting positively on educational institutions and their programs, a number of secondary schools have also adopted information technology fully thus recording improved efficiency in their operations. However, the situation is not the same in all schools because others have been dissatisfied with their investments. For a school to optimally use and benefit from use of IT then it should subject its MIS to the evaluation framework proposed here, by first, addressing the following organization issues; Personnel issues, Technical system issues, Leadership issues, Organization environmental issues and Management Process issues. Furthermore, for successful MIS implementation; all the stakeholders should undergo some training on system use and that the top management should provide enough funding for infrastructure improvement and management of the system.
\end{abstract}

Index Terms- ICT: Information Communication and Technology, IT: Information Technology, IS: Information System, MIS: Management Information System

\section{INTRODUCTION}

$\mathrm{F}^{1,1}$ 1.1 Background Information

prosperity and survival of most organization worldwide, top management in these organizations should at least poss basic information technology (IT) skills. In order to reach more customers in different areas in the world, use of Information Systems (IS) can help companies to launch new products and in general change the way organizations conduct their business processes (Laudon \& Laudon, 2006).

Competition rates have drastically increased globally in the use of IS, this has made it possible for most institutions to be more strategic and tactical to become more effective and efficient. An organization such as an educational institution can suffer a major risk if they decide to stay insensitive to this change.

According to Demir, 2003, there are some factors that may force educational institutions globally to develop new applications in order to survive. Such factors include; modern management perceptions and applications, increasing expectation of the society, information exchange and continuous developments in information technologies

Education has made IT to reach a state of high priority due to the priority of modern societies. According to Webber, 2003; Pelgrum, 2001; Yuen, Law \& Wong, 2003, the most emphasized subject is the contributions of IT to education.

The popularity of information as a major resource in management had been realized as early as 1970's. According to Oyier \& Mwanda, (2011) towards the end of the twentieth century Information and Communication Technology (ICT) was used as a tool for management in the business organizations including educational institutions. Various approaches to information management developed due to the fact that ICT supported decision making processes. MIS provides relevant information which help in making relevant decisions in an organization (Breiter \& Light, 2006).

In any organization where the school is part, the hierarchical organizational structure is normally adopted where manual information system is used. According to Tripathi (2011), there are three important levels of system structure namely; - operational, middle management and top management. In this kind of structure information is passed from operational level to the middle level and finally to the senior management level which is the topmost level. (Laudon \& Laudon (2014) agrees with Tripathi (2011) as presented in figure 1.2 


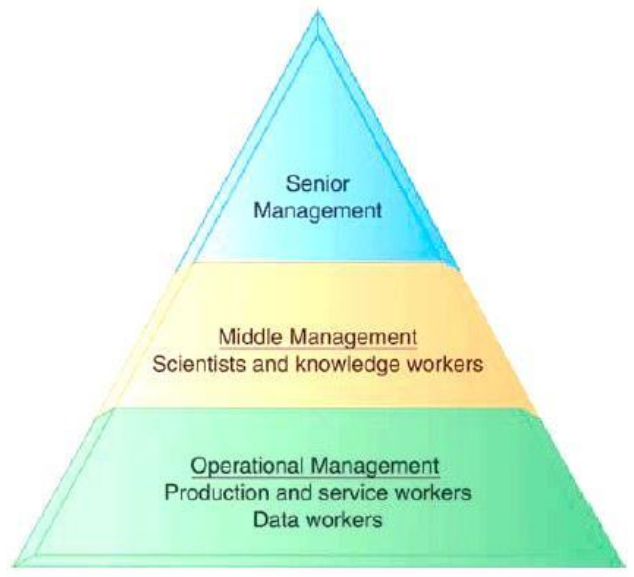

Figure 1.1 :

Organization Level (source: Laudon \& Laudon, 2014)

The above figure can be related to a school setup where the main stakeholders are at the senior management where we have the school Board of Management (BOM), at the Middle management we have the; Head of Departments (HOD), Director of Studies (DOS), Senior masters/Mistresses, Class teachers and at operation Management we have; the Subject teachers, Librarians, Bursars, Workers, Students and Parents.

For secondary schools that have adopted the use of a computer based information system the hierarchical organizational structure can be modified for efficient and effective business processes. In this case the information system would conform to two levels; strategic level and operational level. The strategic level would include the principals and deputy principals while the operational level would include teachers, bursars, librarians and the students/parents/workers as the end user as shown in figure 1.3

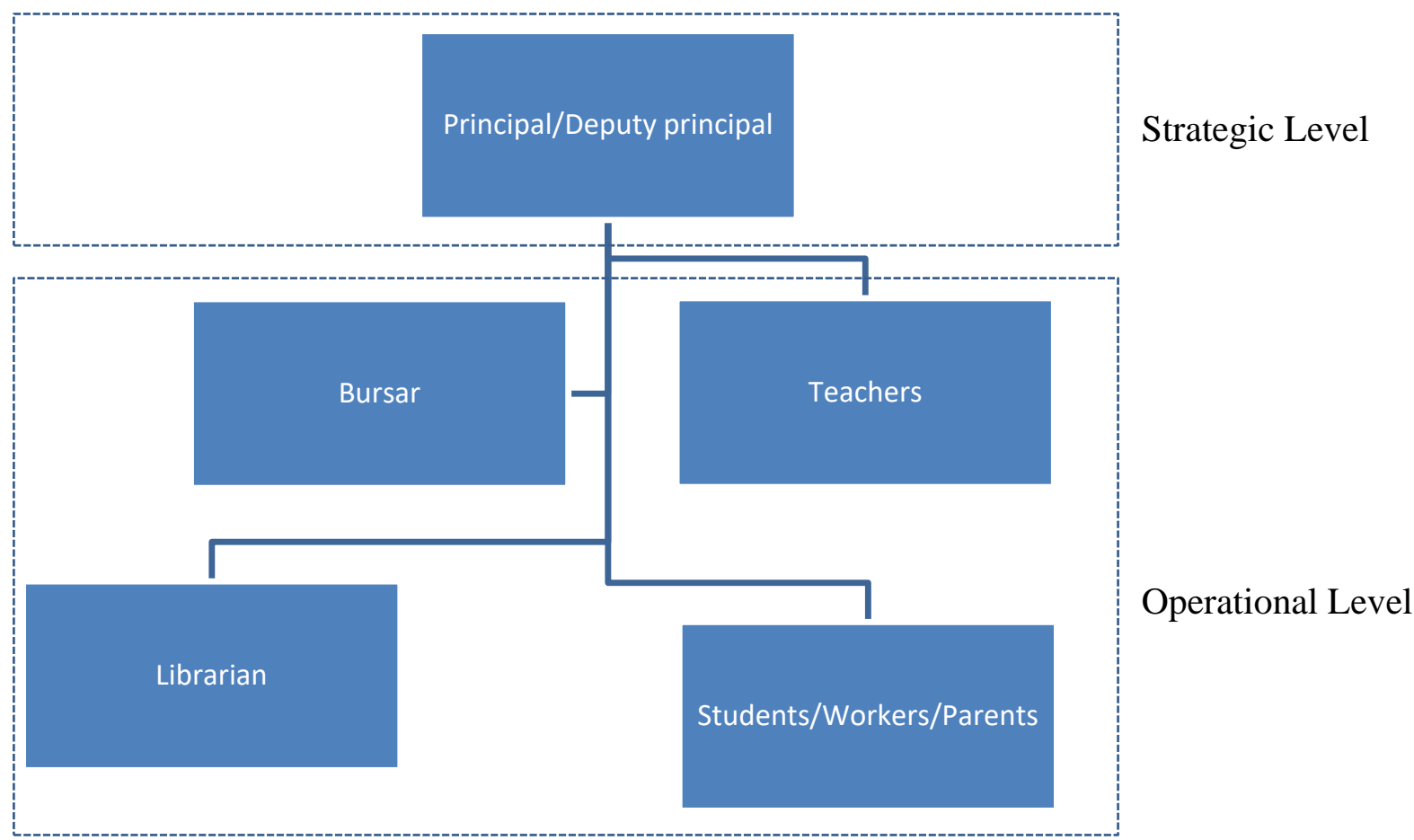

Figure 1.2: Major users/stakeholders of SMIS in secondary school set up (Source: Author 2021)

At the teachers category there exists; the Head of Departments, Head of Subjects, Director of Studies, Senior Masters/Mistresses, Class teachers and Subject teachers.

The levels are dependent on the functionality of the SMIS. Some of the packages included in the system includes; Academics Package, Accounting Package, Store records, Library Records, Accommodation records, Timetable processor, Biometric identification, Student records, Discipline records, Attendance register, Leaving certificates, Student IDs, Pocket money records, Bulk branded short message service, Fee records etc. 
When information system is used to improve the organization management by the managers it becomes a MIS (Ein-Dor and Segev 1978). Management performance can be increased in this case by the system. When tools, manpower and software are collected together to perform various business processes in an organization it is referred to as MIS (Tripathi, 2011). For crucial decision-making purposes MIS plays a very major role such as providing information that directly affects the performance of such organizations (Murthy, 2006). This therefore makes IS to be an integral part of an organization. Notably in some organizations no business can be performed without an IS. The basic components of an organization include; - its people, structure, business process, politics and culture (Laudon \& Laudon, 2014). They stress that an information system is more than computers. Figure 1.4 justifies the above statement.

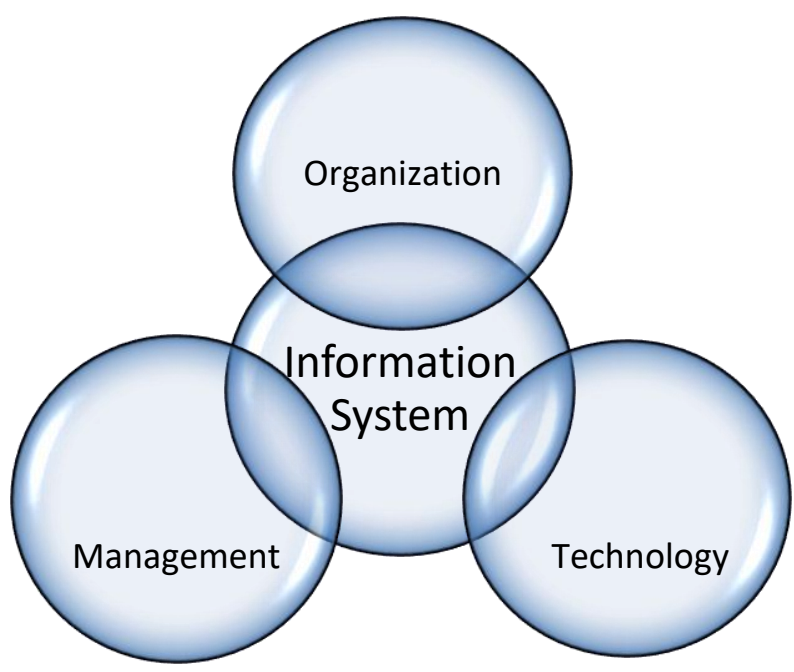

Figure 1.3 : Aspects of Information system (Source: Laudon \& Laudon, 2014)

From figure 1.4 IS also includes; - management, organization and technology. The number of successful implementations of information systems particularly considered in relation to plan execution is relatively low (Dyczkowski, 2007), therefore it is important to perform an evaluation process of information system implementation process. When good evaluation is carried on appropriately it guarantees achieving implementation goals and measurable benefits to the school. An evaluation approach is based initially on three concepts of structure, process and outcome (SPO) (Omwenga \& Rodrigues, 2006). Structure of a system is defined as, the manner in which it is constructed or the whole of its essential parts, while Process performs a series of operations by which a task is accomplished and information transformed, and finally the Outcome of a system is the impact or visible effect or just the general result of the system operation.

\subsection{Background of evaluation frameworks and Theories}

Omwenga \& Rodrigues (2006) evaluation approach agrees with most theories used in evaluation such as the Values Engaged Theory (Green, 2011), Utilization Focused Theory (Patton, 2013), Empowerment Theory (Fetterman, 2012) and the Theory Driven Theory or the Program Theory (Chen, 2015), in that a lot of focus is on the user as an integral stakeholder.

For proper implementation of the system in an organization, the system users should take into account that such systems cannot fully meet all the organization requirements since most researchers are in agreement that even the best designed and tested system cannot meet the actual requirements of an organization (Artit 2012; MacLeod \& MacDonell 2011; Kumar \& Malik 2011).

Most of the common barriers according to Artit (2012) and Laudon \& Laudon (2014) are Organization environment issues, the Leadership issues, Personnel issues, Management process issues and Technical issues. This research proposes a framework comprising the SPO (Rodrigues, 2004) and (Artit, 2012) model. The evaluation framework was guided by the program theory by (Chen, 2015).

\section{METHODS}

\subsection{Related Theories and Frameworks for Information Systems}

From the early twentieth century there have been various developments of methodology to test the effectiveness of several educational programs in school. Evaluation process has evolved in this field and now has developed to a discipline of study, it has provided links with many research disciplines including; social science, public administration, education and public policy. Evaluation has played a major role in different organizations through service delivery process, policy formulation, identification of public need to ensure value and quality of the implemented solutions (Rogers, 2007).

It is worth noting that the processes involved in planning, executing, and evaluating MIS bear many similarities to that planning, implementing and evaluating projects and services in social organizations. Problem identification is key and the actions should be taken 
in order to solve or rectify the already identified problem. The concept of evaluation has been extensively studied in social program setting, surprisingly, the concept of evaluation has been underdeveloped in the SMIS.

No major evaluation has been done in most MIS used in secondary schools in Kenya. Generally, there is no effort to systematically measure key facilities required for successful implementation of SMIS, challenges, outcomes or impacts in a comprehensive manner. Those in leadership positions should find it appropriate to bring together all the information received from various sources and be able to construct an evaluation of progress and results which can bring about new changes in the organization (Curry, 2004; Rauch, 2002). A new field that has emerged from the diverse array of applied social sciences is evaluation. Evaluation is practice oriented; it is of importance to note that there has been a rapid increase of research on evaluation theory to lay down rules underlying frameworks of evidence-based practice. The main role of evaluation theory is to specify convenient practices that evaluators can use to come up with knowledge about the value of social programs (Shadish, Cook, \& Leviton 1991). The main five components which comes out clearly from the above explanation of evaluation theories are use, practice, valuing knowledge and social programming.

Methodology is mainly considered in evaluations. But a more considerate approach starts with theory before methodology. The purpose of evaluation should be considered first to determine its theoretical foundation is when evaluation questions are considered to inform the methodology. Most evaluations always focus on the technical details of the evaluation rather than the overall purpose. When focus is made on the theory at the beginning of the project, it ensures that the process, that is, stakeholder involvement, methodology, data collection, analysis and reporting is intentional, purposeful and more useful for the client.

The section below discusses some of the evaluation theories when put in practice can bridge the gap between evaluation theory and practice. Table 2.1 summarizes the theories and frameworks, with their merits and demerits. 
Table 2.1 : Related Theories and Frameworks

\begin{tabular}{|c|c|c|c|}
\hline Evaluation Theory & Brief description & Merits & Demerits \\
\hline $\begin{array}{l}\text { Values Engaged Theory. } \\
\text { (Greene, 2011). }\end{array}$ & $\begin{array}{l}\text { Provides contextualized } \\
\text { understandings of social } \\
\text { programs that have particular } \\
\text { promise for underserved and } \\
\text { underrepresented populations }\end{array}$ & $\begin{array}{l}\text { It encourages the } \\
\text { evaluators to include all } \\
\text { relevant stakeholders. }\end{array}$ & $\begin{array}{l}\text { Cannot address all the } \\
\text { purposes and audiences }\end{array}$ \\
\hline $\begin{array}{l}\text { Utilization Focused Theory } \\
\text { (Patton, 2013). }\end{array}$ & $\begin{array}{l}\text { It is on the premise that } \\
\text { evaluations should be judged by } \\
\text { their utility and actual use }\end{array}$ & $\begin{array}{l}\text { The evaluator involves } \\
\text { intended users at every } \\
\text { stage of the process. }\end{array}$ & $\begin{array}{l}\text { Its improvement is } \\
\text { driven by a psychology } \\
\text { of use. Which does not } \\
\text { happen naturally }\end{array}$ \\
\hline $\begin{array}{l}\text { Empowerment Theory } \\
\text { (Fetterman, 2012). }\end{array}$ & $\begin{array}{l}\text { Was developed as an approach } \\
\text { to foster program improvement } \\
\text { through empowerment and self- } \\
\text { determination }\end{array}$ & $\begin{array}{l}\text { It seeks to increase the } \\
\text { probability of program } \\
\text { success by providing } \\
\text { stakeholders with the } \\
\text { tools and skills to self- } \\
\text { evaluate and } \\
\text { mainstream evaluation } \\
\text { within an organization }\end{array}$ & $\begin{array}{l}\text { It overburdens the } \\
\text { evaluator i.e. evaluators' } \\
\text { role is to empower } \\
\text { stakeholders to take } \\
\text { ownership of the } \\
\text { evaluation process }\end{array}$ \\
\hline $\begin{array}{l}\text { Theory Driven } \\
\text { Theory) } \\
\text { (Chen, 2015) }\end{array}$ & $\begin{array}{l}\text { The focus is on the theory of } \\
\text { change and causal mechanisms } \\
\text { underlying the program. }\end{array}$ & $\begin{array}{l}\text { 1. Relies on change } \\
\text { model and action } \\
\text { model. } \\
\text { 2. Provides a useful tool } \\
\text { to probe the validity of } \\
\text { an evaluation and can } \\
\text { assist in identifying and } \\
\text { controlling extraneous } \\
\text { sources of variance } \\
\text { 3. Can be applied even } \\
\text { in most sophisticated } \\
\text { experimental } \\
\text { evaluations to explain } \\
\text { what factors were } \\
\text { responsible for the } \\
\text { program's success - or } \\
\text { failure } \\
\text { 4. Allows evaluators to } \\
\text { include all relevant } \\
\text { stakeholders at every } \\
\text { stage of the program }\end{array}$ & $\begin{array}{l}\text { 1. It is resource and data } \\
\text { intensive } \\
2 . \text { It is notoriously } \\
\text { difficult to construct and } \\
\text { the level of granularity } \\
\text { to which the evaluator } \\
\text { must go is often } \\
\text { uncertain; multiple } \\
\text { theories are possible }\end{array}$ \\
\hline $\begin{array}{llr}\text { Technology } & \text { Mediated } \\
\text { Learning: } & \text { Evaluation } \\
\text { Framework } & & \\
\text { (Omwenga } \& & \text { Rodrigues, } \\
\text { 2006) } & & \end{array}$ & $\begin{array}{l}\text { This framework was used to } \\
\text { evaluate e-learning programs }\end{array}$ & $\begin{array}{l}\text { Allows the impact of an } \\
\text { information system on } \\
\text { e-learning to be } \\
\text { evaluated at three } \\
\text { levels: the structure, the } \\
\text { process, and the } \\
\text { outcome. It also } \\
\text { assesses from different } \\
\text { stakeholder viewpoint: } \\
\text { that of planners, }\end{array}$ & $\begin{array}{l}\text { Understanding of the } \\
\text { SPO model at times is } \\
\text { challenging to some } \\
\text { people. }\end{array}$ \\
\hline
\end{tabular}




\begin{tabular}{|c|c|c|c|}
\hline & & $\begin{array}{l}\text { providers and } \\
\text { consumers. It includes } \\
\text { the system perspective } \\
\text { such as: technical } \\
\text { system's functioning, } \\
\text { human perspective and } \\
\text { education impact } \\
\text { It provides a procedure } \\
\text { that assesses the } \\
\text { technical and the social } \\
\text { aspects of a system, as } \\
\text { well as the long-term } \\
\text { impact on improving } \\
\text { education provision. } \\
\text { It is a standardized } \\
\text { procedure for reporting } \\
\text { evaluation results that } \\
\text { may be widely applied. }\end{array}$ & \\
\hline $\begin{array}{l}\text { The Artit framework } \\
\text { (Artit, 2012) }\end{array}$ & $\begin{array}{l}\text { It assesses the implementation } \\
\text { challenges, success Key issues, } \\
\text { effects and consequences }\end{array}$ & $\begin{array}{l}\text { It Details key issues for } \\
\text { MIS implementation } \\
\text { success which } \\
\text { influence the MIS } \\
\text { implementation } \\
\text { process. It discusses } \\
\text { organizational impacts } \\
\text { focusing on effects and } \\
\text { consequences which } \\
\text { are manipulated by } \\
\text { implementing MIS } \\
\text { within the organization. }\end{array}$ & $\begin{array}{l}\text { It was a frame work } \\
\text { which heavily relied on } \\
\text { military use, but can be } \\
\text { adopted for educational } \\
\text { use. }\end{array}$ \\
\hline
\end{tabular}

\section{Source: Author 2021}

\subsubsection{Values Engaged Evaluation Theory (VEE)}

This theory was developed by Jennifer Greene, as a democratic approach that is highly responsive to context and emphasizes stakeholders' values. The theory seeks to provide contextualized understandings of social programs that have particular promise for underserved and underrepresented populations (Greene, 2011). The reason why it is considered a democratic approach is because it encourages the evaluators to include all relevant stakeholders.

The main challenge of program evaluation is that, while all these purposes and audiences are legitimate, any one evaluation study cannot address all of them, so choice - sometimes difficult ones need to be made. Greene offers three points why it is important to include the stakeholder's values. They are as follows; -

a) It increases the chance of use, that is, it is pragmatic.

b) It empowers the stakeholders

c) It considers all interest

With this approach, evaluation design and methodology evolve as the evaluator understands the context needs; and values underlying the program.

VEE is mainly concerned with answering broad and in-depth questions, and is more suited for formative rather than summative evaluations. Values engagement has two main dimensions; first it signals purposeful attention to the values that are intrinsic in education programs including value differences that may be present among key program stakeholders and the second point is that it pays special attention to the values of diversity and equity (Greene, 2011). Greene's work focuses on the practice of evaluation, not on the technical or methodological components of the evaluators work i.e. it assumes basic methodological proficiency.

The point here is for the evaluator to seek opportunities to surface understandings, values, assumptions and underlying rationales of the program design and implementation from multiple perspectives (Greene, 2011)

\subsubsection{Utilization - Focused Evaluation Theory (U-FE)}

This theory was developed by Michael Quinn Patton, on the premise that evaluations should be judged by their utility and actual use (Patton, 2013). The application of this theory is done when there is need for discrete decision making.

U-FE focuses on intended users. Stakeholder identification is key when engaging the primary intended users, Patton, (2013) stresses on personnel factor. At every stage of the evaluation the intended users are involved. The ultimate purpose of U-FE is 
programmatic improvement driven by a psychology of use. Intended users are more likely to use the evaluation if they feel ownership of the process and its results. Use does not happen naturally; therefore, the evaluator must reinforce utility by engaging intended users at each stage of the evaluation.

\subsubsection{Empowerment Evaluation Theory}

This theory was developed by David Fetterman, as an approach to foster program improvement through empowerment and selfdetermination (Fetterman, 2012). Self - determination theory describes an individual's agency to chart his or her own course in life and the ability to identify and express needs. In this theory it is believed that the evaluators' role is to empower stakeholders to take ownership of the evaluation process as a vehicle for self-determination. This theory also seeks to increase the probability of program success by providing stakeholders with the tools and skills to self-evaluate and mainstream evaluation within an organization. The steps for conducting empowerment evaluation includes (1) Develop and refine the mission, (2) take stock and prioritize the program's activities, and (3) plan for the future.

\subsubsection{Theory - Driven Evaluation Theory (Program theory)}

Huey Chen is one of the main contributors to this theory. He focuses on the theory of change and causal mechanisms underlying the program. Chen, (2015) recognizes that programs exist in an open system, consisting of inputs, outputs, outcomes, and impacts. According to Chen, evaluators should start by working with stakeholders to understand the assumptions and intended logic behind the program. To illustrate the causal relationships between activities and outcomes, a logic model can be used.

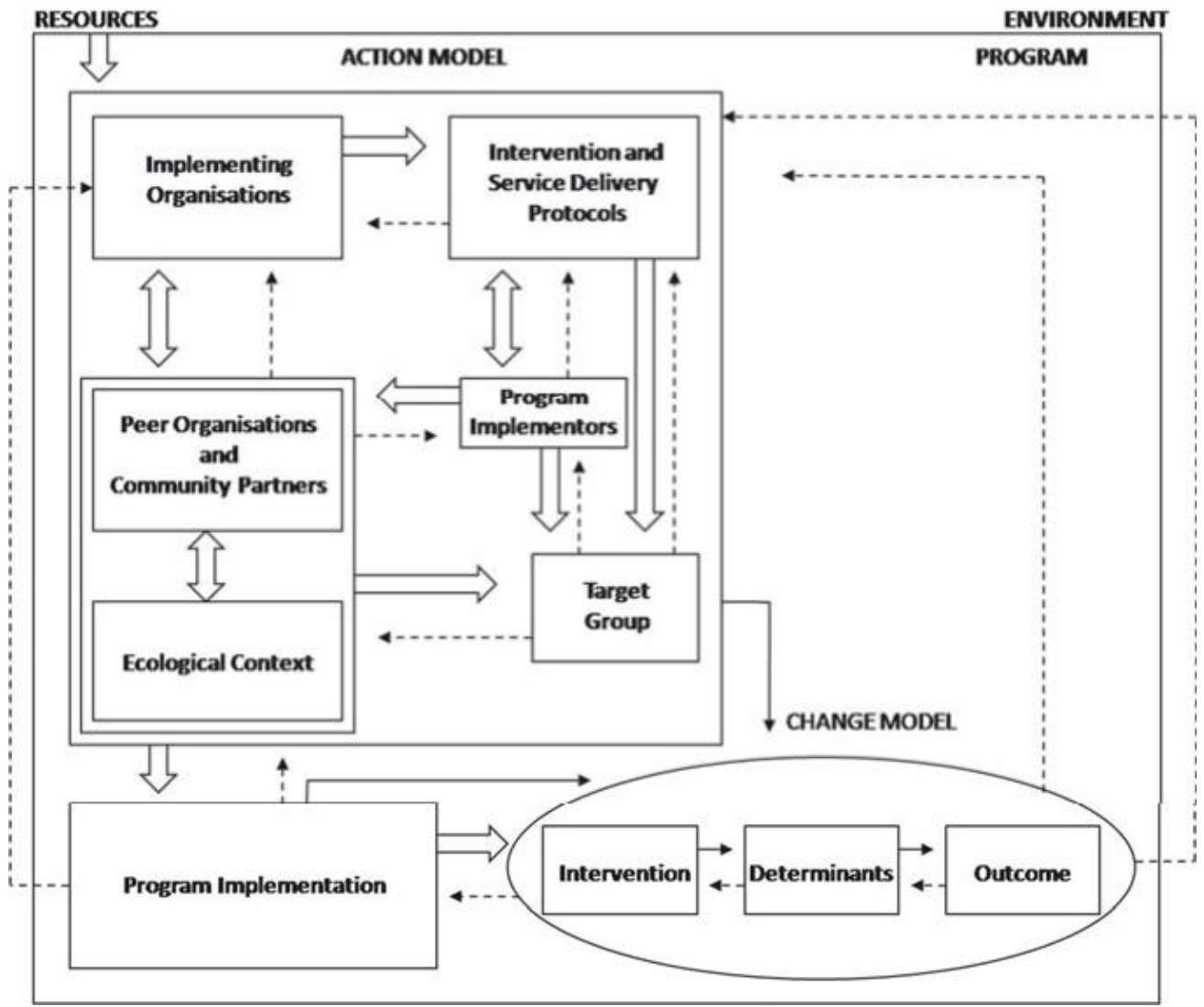

Figure 2.1: Program Theory Framework

Source: Chen H-T. Practical Program Evaluation, Thousand Oaks, CA: Sage Publications, 2005.

Many suggestions have been offered for constructing program theory models, such as action model (i.e. systematic plan for arranging staff, resources, settings to deliver services) and change model (i.e. set of descriptive assumptions about causal processes underlying intervention and outcome) Chen, (2015).

Chen suggests that evaluators should consider this approach when working with program implementers to produce valuable information for formative program improvement.

A review by Lipsey Crosse, Dunkle, Pollard, and Stobart (1985) of 175 evaluation studies noted that "most of the programs... evaluated did not provide simple structured treatment that could be expected to work through readily apparent mechanisms". In fact, one of the main reasons for the growing interest in theory-driven evaluation was "the usual inability of even the most sophisticated experimental evaluations to explain what factors were responsible for the program's success - or failure" (Weiss, 1997a) 
Although some evaluators argued that the focus of any evaluation should be on the quality, value, and success of any implemented program (Scriven, 1994), theorists recognized that failing to identify the underlying causal mechanisms that led to program success would not allow deficiencies in either program implementation or program design to be suitably identified and addressed (Chen, 1994), thus program improvement was seen as a key goal in any program evaluation (Chen, 1994; Posavac \& Carey, 2006; Rogers, 2000). The defining characteristics of theory-driven evaluation is that the assumptions and mechanisms behind a program can be expressed in a logical sequence of cause and effect statement - also known as program theory (Weiss, 1997a)

Donaldson (2007) noted that theory-driven evaluation provides a useful tool to probe the validity of an evaluation and can assist in identifying and controlling extraneous sources of variance. Chen (2005), Sullivan \& Stewart (2006) further noted that program theory provides a strategy to incorporate stakeholder views in the program design and evaluation.

Theory-driven evaluation is not without its disadvantages and its critics. Weiss (1997a) - a leading proponent of the technique described key challenges in theory-driven evaluation: program theory is notoriously difficult to construct and the level of granularity to which the evaluator must go is often uncertain; multiple theories are possible - often requiring multiple sets of measurement indicators - thus, the technique is resource and data intensive; and by focusing on the program theory, the evaluator may ignore many other important effects and causes (see also Shaw \& Crompton, 2003). Others have noted that although program theory may provide focus to an evaluation, it provides a focal point of the evaluation (English \& Kaleveld, 2003). Finally, it has been pointed out that in reality, few social science theories actually exist for the program areas that evaluators typically face, thus evaluator often begins with a grounded theory approach in developing program theory (Stufflebeam, 2001).

\subsubsection{Technology Mediated Learning: Evaluation Framework}

Salomon (1991) describes the contrast between analytic and systemic approaches to research that transcends the "basic versus applied" or "quantitative versus qualitative" arguments that so often dominate debates about the relevancy of educational research. Salomon concludes that the analytic and systemic approaches are complementary, arguing that "the analytic approach capitalizes on precision while the systemic approach capitalizes on authenticity".

According to Omwenga and Rodrigues (2006), any technology mediation for educational purposes has a structure, a process and a learning outcome (SPO) which can be viewed from three main systems perspectives: that of the technical system functioning, human perspectives of those involved, and the overall impact on the education system. A matrix diagonal resulting from the overlay are technical standards; organizational infrastructure and social interaction; and educational status and developmental potential of target population. By extending this framework more fully into a matrix we may explore and study broader and more comprehensive relationships (Omwenga and Rodrigues, 2006). For example, when the structure (or design) of a system is considered in terms of its overall impact on the educational system, one can appreciate the opportunities and challenges that arise in implementing interactive learning across emerging economies see figure 2.2 below.

\begin{tabular}{|c|c|c|c|c|}
\hline \multirow{3}{*}{ 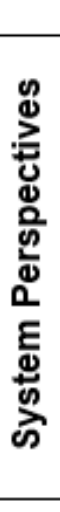 } & \multirow{2}{*}{ 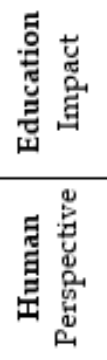 } & $\begin{array}{l}\text { Balance of education } \\
\text { provision, management } \\
\text { and training } \\
\text { requirements }\end{array}$ & $\begin{array}{l}\text { Altered practice and } \\
\text { delivered quality } \\
\text { in education systems }\end{array}$ & $\begin{array}{c}\text { Educational status and } \\
\text { developmental } \\
\text { potential of target } \\
\text { population }\end{array}$ \\
\hline & & $\begin{array}{c}\text { Work conditions } \\
\text { and } \\
\text { imposed requirements }\end{array}$ & $\begin{array}{l}\text { Organizational } \\
\text { infrastructure } \\
\text { and } \\
\text { social interaction }\end{array}$ & $\begin{array}{c}\text { Change in perception } \\
\text { of } \\
\text { Educational service } \\
\text { quality }\end{array}$ \\
\hline & 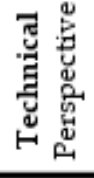 & $\begin{array}{c}\text { Technical } \\
\text { detail }\end{array}$ & $\begin{array}{l}\text { Correctness and } \\
\text { validity: learning } \\
\text { delivery system } \\
\text { methodology }\end{array}$ & $\begin{array}{l}\text { Compliance with } \\
\text { education requirement } \\
\text { specifications }\end{array}$ \\
\hline & & $\begin{array}{l}\text { Structure } \\
\text { (design) }\end{array}$ & $\begin{array}{c}\text { Process } \\
\text { (Modalities to achieve } \\
\text { learning) }\end{array}$ & $\begin{array}{c}\text { Outcome } \\
\text { (Learning impact) }\end{array}$ \\
\hline & & & hnology Mediati & \\
\hline
\end{tabular}

Fig 2.2: Technology Mediated Learning: Evaluation Framework (Source; Omwenga \& Rodrigues, 2006)

According to Omwenga and Rodrigues (2006), the justification of the above approach provides a procedure that assesses the technical and the social aspects of a system, as well as the long-term impact on improving education provision, and it is also a standardized procedure for reporting evaluation results that may be widely applied. In summary, the technology mediated framework 
permits a structured view of interactive learning projects which recognizes both the need to link the technology grounded applications with ones that involves a more fundamental understanding of the broader concept of the value of education.

\subsubsection{The Artit framework}

Artit, (2012) came up with a framework to assess the implementation challenges, success Key issues, effects and consequences when he did a case study on a Fenix System (an MIS) used in the military. His framework is shown in figure 2.3 below;

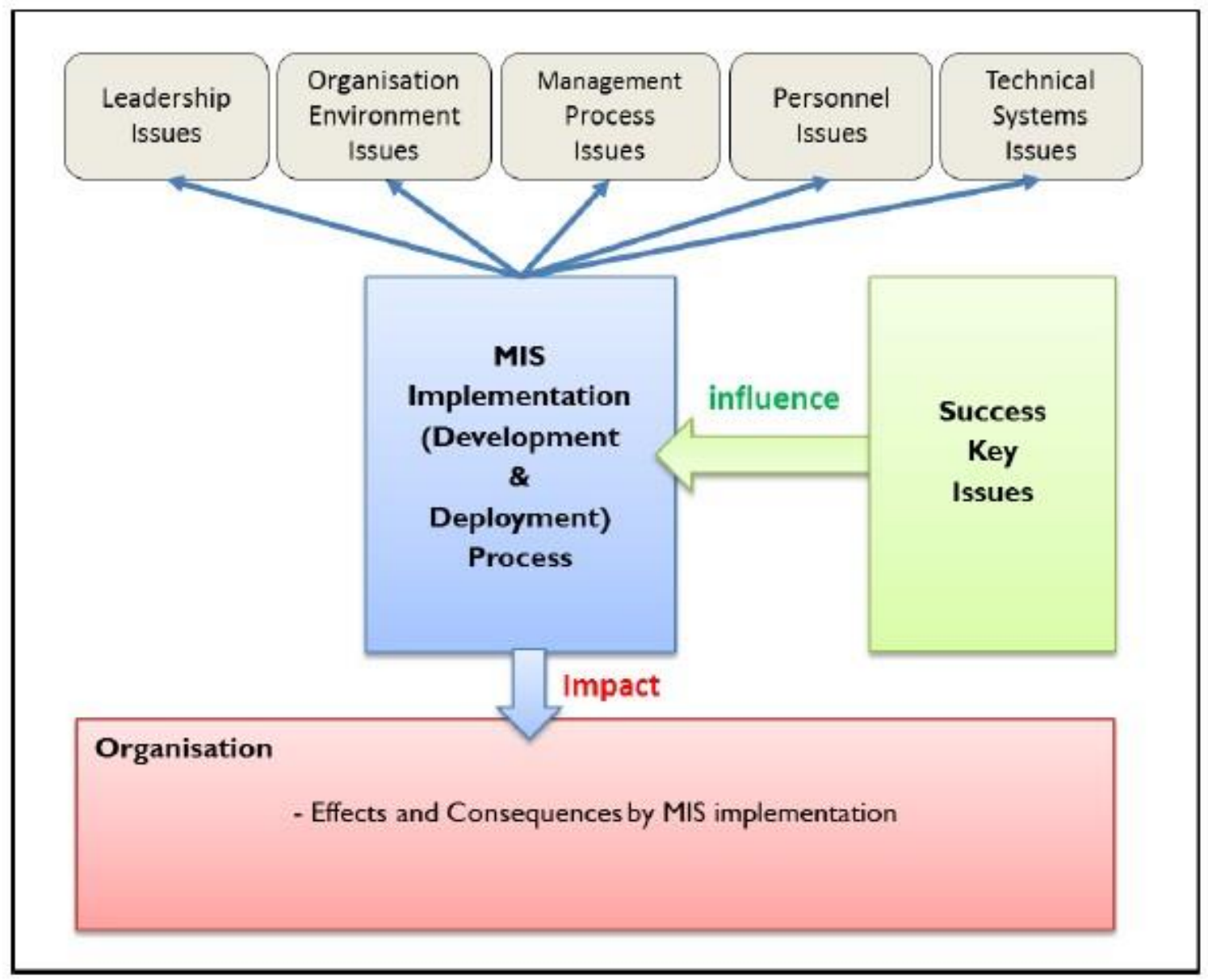

Figure 2.3

Artit MIS Framework (Source: Artit, (2012) pg. 28)

He argues that the implementation challenges can be broken down by issue type and they can be categorized into five issues including: leadership issues, organization environment issues, management process issues, personnel issues, and technical systems issues. Further, he introduces the key issues for MIS implementation success which influence the MIS implementation process. These success factors can be viewed as tools which increase degrees of implementation process improvement and support in each stages of the implementation process (Artit, 2012). In addition, a significant role of these success factors is the contribution to the success of MIS implementation. The last element in the model is organizational impacts focusing on effects and consequences which are manipulated by implementing MIS within the organization.

In conclusion the Chen's framework (2015) can be fused with the Omwenga \& Rodrigues (2006) framework to assist in the evaluation of MIS as was assessed by Artit, (2012). This integration will yield a new evaluation framework for SMIS

The study was based on the integration of program theory, Technology Mediated Learning: Evaluation Framework and the Artit framework.

\section{The Program theory}

The theory focuses on the stakeholders which is the key reference to the research work

\section{Technology Mediated Learning: Evaluation Framework}

This approach was adopted because it details the structure, process and outcome of an evaluation of MIS which forms the basis of the research 


\section{The Artit Framework}

This framework identifies the key issues affecting an organization, which was also important in the research during the evaluation process

\subsection{The Developed proposed evaluation framework for school management information systems for secondary schools}

A multiple regression analysis was used to evaluate the proposed framework shown in figure 2.3 below and the results discussed below indicate that the model is useful as predictor of the status of school information management systems. The challenges facing the implementation process and the key success issues were considered under the SPO framework as shown in the figure 2.4

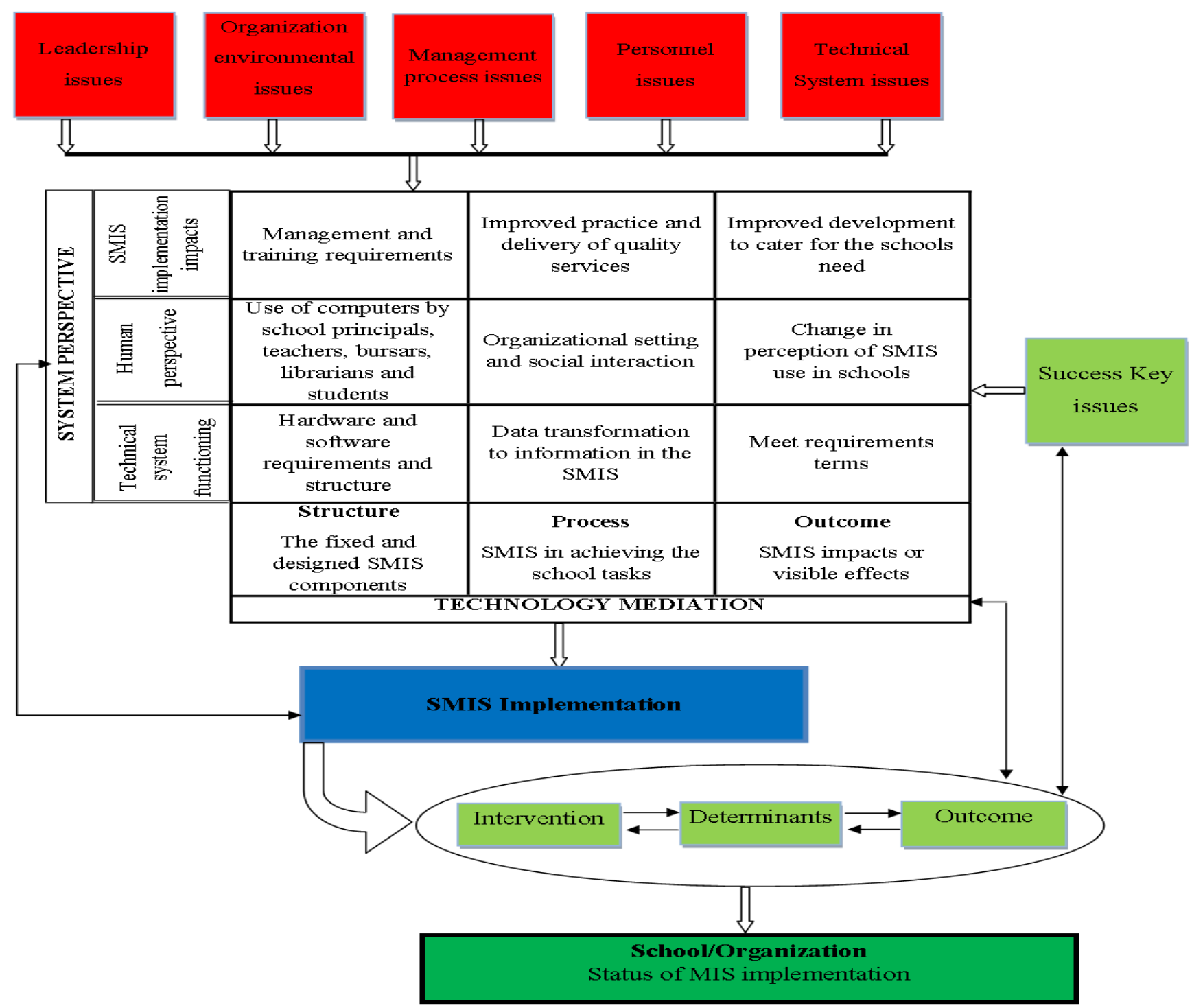

Figure 2.4 the proposed Evaluation framework of School Management Information System (Source: Author, 2021)

Multiple regression, an extension of simple linear regression is used to predict the value of a variable based on the value of two or more other variables. The variable to be predicted, called the dependent variable (the outcome, target or criterion variable) in this study is the status of school management information systems (STATUSSMIS). The variables used to predict the value of the dependent variable are called the independent variables (the predictor, explanatory or regressor variables) are System perspectives, SYSPERS and technical mediation, TECHMED, transformed from the survey questionnaire items that tested for each of the independent variables. Typically, mean scores are calculated after it has been established that these specific items load on one factor. The composite/mean score is simply a sum or mean where all items get the weight Olawale Fatoki (2018) in his study on "The impact of entrepreneurial resilience on the success of small and medium enterprises in South Africa", Ofunoye (2017) in his work "Innovation and Resilience of Small-Medium Entrepreneurs in Port Harcourt" and Davidson in "Interpreting performance in small business research" all used the concept of finding the mean of items testing one variable. Before finding the mean scores, the correlations between the questionnaire items was tested and the few items that had extremely high correlations merged. All items on the system perspective component were 
merged as SYSPERS, using the values of their sum and mean. Similarly, all items on technical mediation and status of SMIS were combined.

Multiple regression enabled the understanding of whether the status of the SMIS could be predicted based on system perspectives and technical mediation. It also helped to determine the overall fit (variance explained) of the model and the relative contribution of each of the predictors to the model. This was achieved by finding out how much of the variation in status of the SMIS could be explained by predictors together and the individual relative contribution. Before starting the regression analysis, all the variables were tested for assumptions required of them to give valid regression analysis output. These assumptions and their findings are discussed below.

\subsubsection{Assumptions}

A regression analysis can only be undertaken if most of the assumptions that include the types of variables used, outliers, multicollinearity, homoscedasticity, independence of errors, normal distribution and linearity are met. These assumptions are explained in the discussion that follows.

\subsubsection{Variable types}

For a multivariate logistical regression all independent variables must be quantitative or categorical with two categories. This study used the transformed variables of all the cases which are, therefore quantitative. The assumption of non-zero variance, implying that the predictors should have variations in value was also met given that all the values between and within the predictors differs for all cases.

\subsubsection{Outliers and influential cases}

Table 2.2 Test for outliers and influential cases.

\begin{tabular}{llllll}
\hline Residuals Statistics $^{\mathbf{a}}$ & \multicolumn{1}{l}{} \\
\hline & Minimum & Maximum & Mean & Std. Deviation & $\mathrm{N}$ \\
\hline Predicted Value & 1.4208 & 4.3067 & 3.0000 & 1.04846 & 22 \\
\hline Std. Predicted Value & -1.506 & 1.246 & .000 & 1.000 & 22 \\
\hline $\begin{array}{l}\text { Standard Error of Predicted } \\
\text { Value }\end{array}$ & .142 & .366 & .213 & .065 & 22 \\
\hline Std. Residual & -1.310 & 1.266 & .000 & .894 & 22 \\
\hline Cook's Distance & .008 & 1.110 & .223 & .323 & 22 \\
\hline Centered Leverage Value & .020 & .652 & .182 & .179 & 22 \\
\hline a. Dependent Variable: SMISSTATUS & & & & \\
\hline
\end{tabular}

As observed from the table 4.23 above, no case has a greater Cook's distance than 1 (average Cook's distance $=0.223$ ). This indicates that none of the cases has an excessive or unjustified influence on the overall model. Furthermore, the table provides the centered leverage values. The average leverage value is $0.17(k+1 / n=4 / 23)$. Values which are twice $(0.34)$ or three $(0.51)$ times as large can indicate influential cases. In this case, the Centered Leverage Value is 0.182 and therefore, the cases presented do not unduly influence the data.

\subsubsection{Multicollinearity}

The multicollinearity assumption requires that there should not be a perfect linear relationship between two or more of the predictors (Field, 2009). A problem with collinearity is present when the tolerance value is less than 0.1. For all independent variables the tolerance value is higher than 0.1. Furthermore, the variance inflation factors (VIF) should not have a 'value greater than 10 . Therefore, all values fall within the allowed range $(\mathrm{VIF}=2.093)$ and neither the tolerance nor the VIF values indicate a problem with collinearity. 
Table 2.3 Collinearity tests for multicollinearity.

\begin{tabular}{|c|c|c|c|c|c|c|}
\hline \multicolumn{7}{|c|}{ Collinearity Diagnostics ${ }^{a}$} \\
\hline \multirow[b]{2}{*}{ Model } & \multirow[b]{2}{*}{ Dimension } & \multirow[b]{2}{*}{ Eigenvalue } & \multirow[b]{2}{*}{ Condition Index } & \multicolumn{3}{|c|}{ Variance Proportions } \\
\hline & & & & (Constant) & SYSPERSPECTIVE & TECHMED \\
\hline \multirow[t]{3}{*}{1} & 1 & 2.877 & 1.000 & .01 & .01 & .01 \\
\hline & 2 & .085 & 5.833 & .95 & .07 & .20 \\
\hline & 3 & .038 & 8.653 & .03 & .92 & .79 \\
\hline
\end{tabular}

a. Dependent Variable: SMISSTATUS

From table 2.3 above, the condition index values are less than 15 . A condition index greater than 15 indicates a multicollinearity problem and greater than 30 is a serious problem that may rule out regression analysis. This result further indicates that assumption of multicollinearity is met.

\subsubsection{Homoscedasticity}

The plot of the standardized residuals, the standardized difference between actual score and predicted criterion variable from the model versus standardized predicted values allow for evaluation of the normality and homoscedasticity assumptions made when testing the significance of the model and its parameters. An observation of the scatterplot by eye enables the determination of violation of these assumptions. Points in the scatterplot should be relatively random, evenly dispersed and linear. If the normality assumption has been met, then a vertical column of residuals at any point on the horizontal line at residual equal zero line will be normally distributed. The density of the plotted symbols will be greatest near that line and drop quickly away from the line and are symmetrically distributed on either sides of the line. If the homoscedasticity assumption has been met, then the spread of the dots, in the vertical dimension will be the same at any one point on that line as it is at any other point on that line. The residuals at each level of the predictors are expected to similar variances to meet the assumption of homoscedasticity (Field, 2009).

Dependent Variable: SMISSTATUS

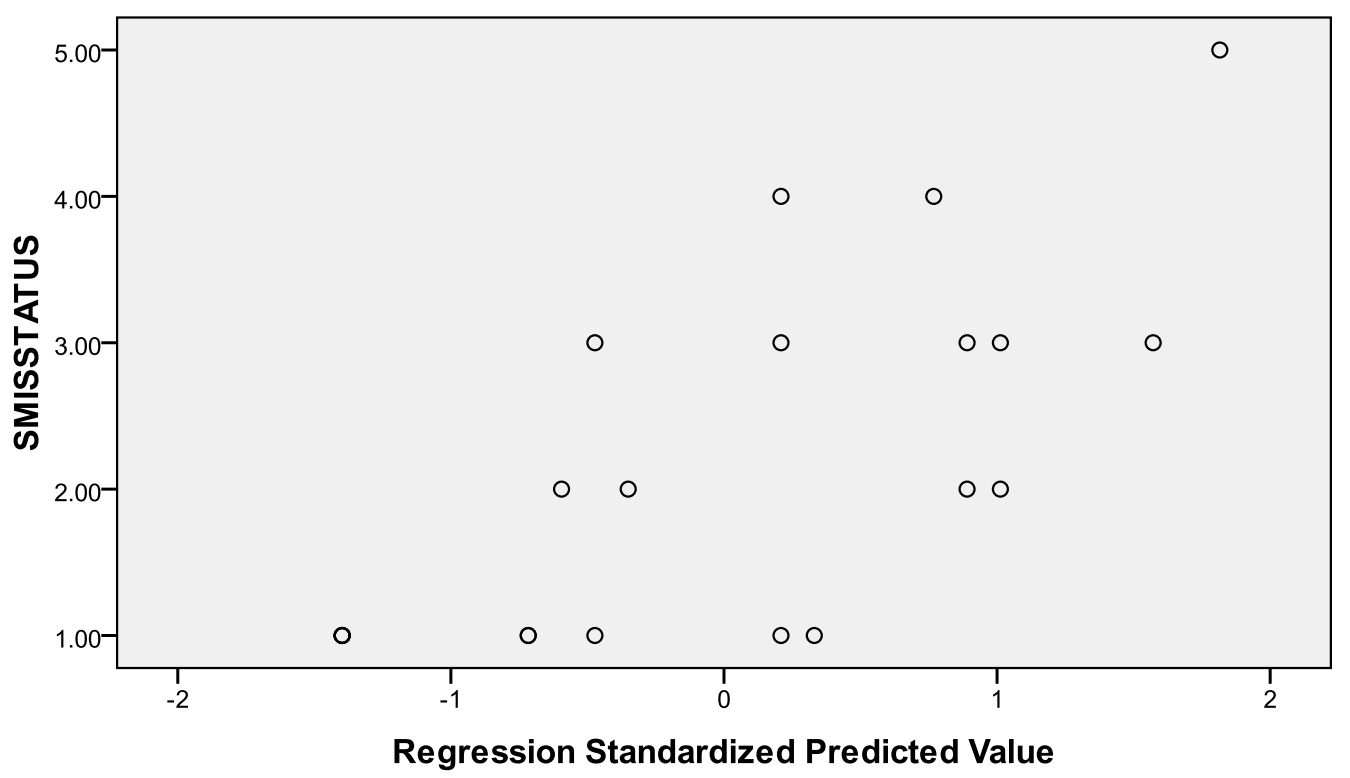

Figure 2.5a. scatterplot to test for homoscedasticity for status of SMIS values. 
Dependent Variable: SMISSTATUS

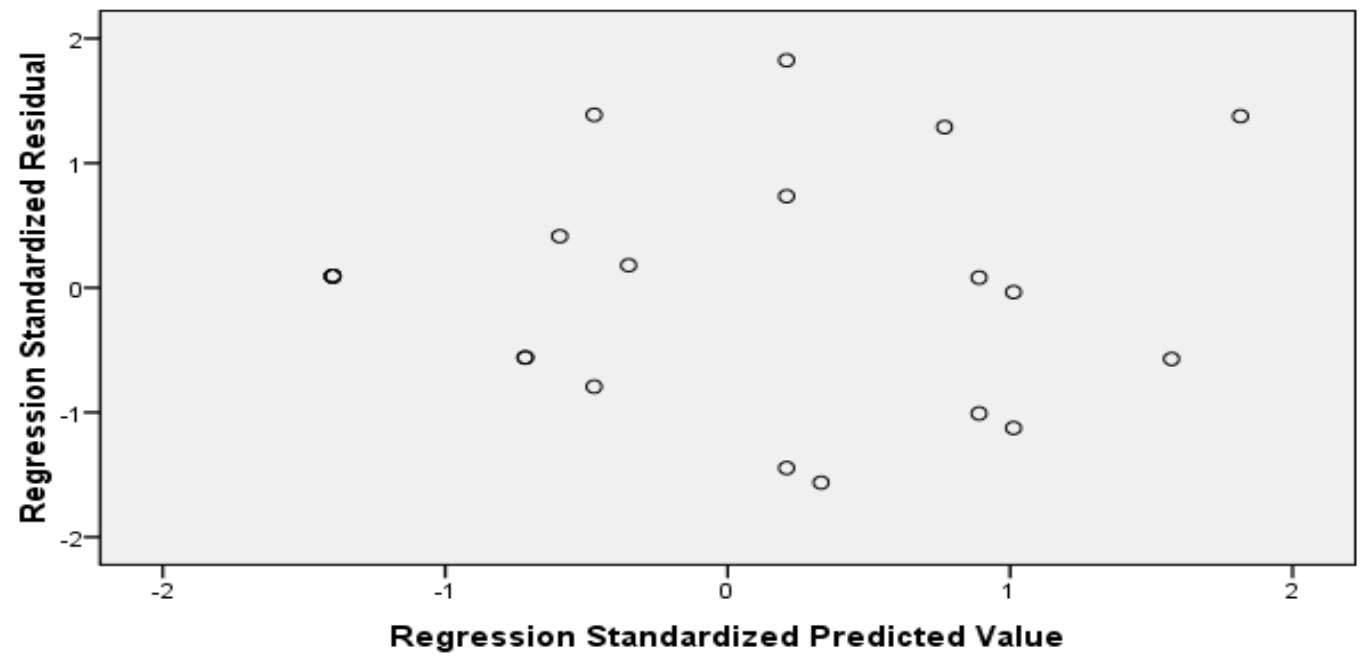

Figure 2.5b. scatterplot to test for homoscedasticity for status of SMIS values.

Dependent Variable: SMISSTATUS

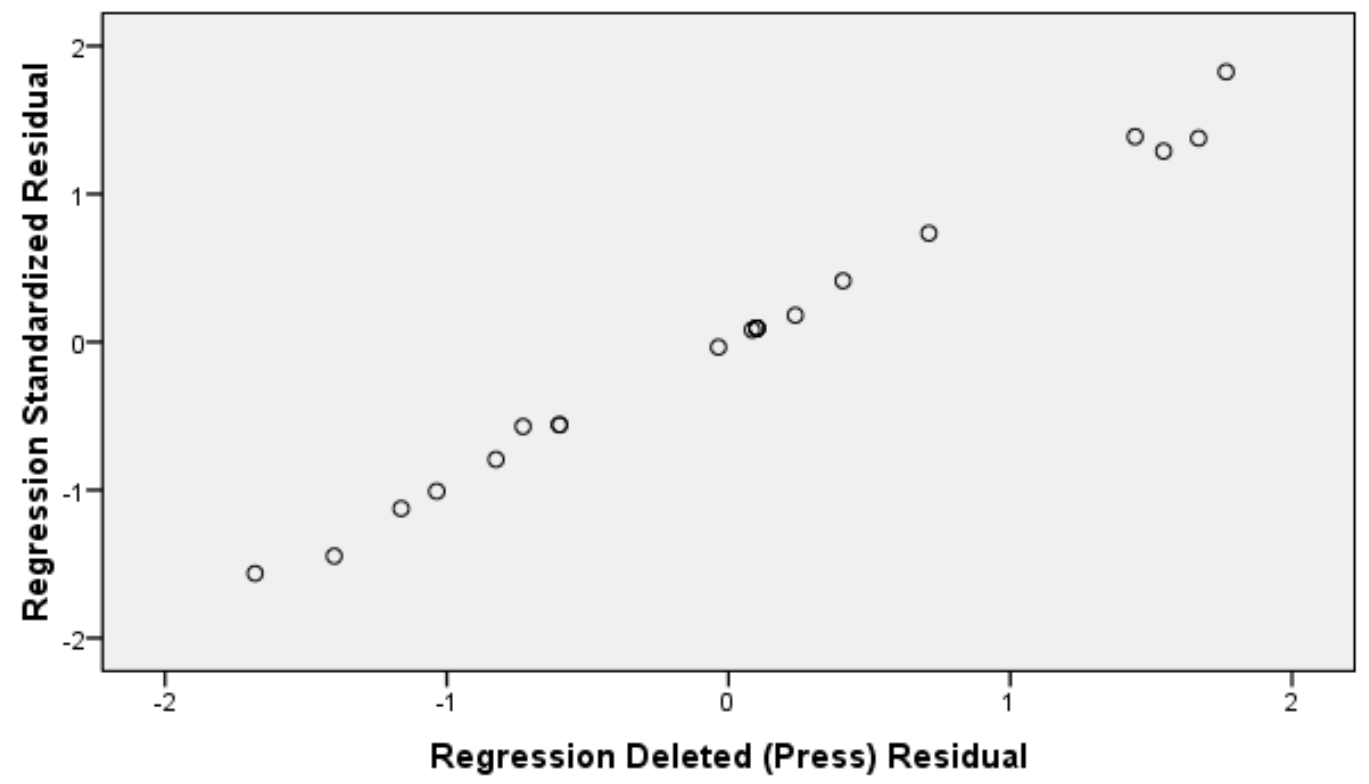

Figure 2.5(c). scatterplot to test for homoscedasticity for status of SMIS values.

From observation of figure $2.5 \mathrm{a}$, the data seems not to violate the assumption of linearity. The points in the graph appear to be relatively random and evenly dispersed. The normality assumption appears to have been met as the density of the plotted symbols seem to be greatest near the line where residuals equal zero and drop quickly away from the line. They appear to be symmetrically distributed on both sides of the line as seen in figure $2.5 \mathrm{~b}$. The homoscedasticity assumption also seems to have been met as the spread of the dots in the vertical dimension look the same at all points on that line. Observation of the residuals plot patterns by the eye suggests a linear relationship between predictors and criterion variables in figure $2.5 \mathrm{c}$. Therefore, both linearity and homoscedasticity assumptions are met. The residuals at each level of the predictors have similar variances in table 2.3 where it is apparent that none of the cases has a standardized residual less than -2 or greater than 2 and hence this assumption is met.

\subsubsection{Independence of errors}

Another assumption concerns independent errors and the Durbin-Watson test is a frequently used method. In essence, for any two observations the residual terms should be uncorrelated. The test statistic ranges between 0 and 4 and a value of 2 implies that the residuals are uncorrelated (Field, 2009). In our model, the Durbin-Watson value is 1.913, nearly equal to 2 indicating that the residuals are likely to be uncorrelated. Hence, the assumption appears to have been met. 


\subsubsection{Normal distribution.}

To determine normal distribution the distribution of residuals is used. According to Field (2009) it is assumed that the residuals in the model are random, normally distributed variables with a mean of 0 and a standard deviation of 1 . The differences between the model and the observed data are expected to be zero or nearly zero and that difference much greater than zero should be very infrequent (Field, 2009). The table 2.3 indicates the minimum residual is -1.310 while maximum is 1.266 with mean of 0.000 and standard deviation of 0.894 , almost equal to 1 . Therefore, the data does not violate the assumption of normal distribution.

For further examination of the residuals the standardized residuals were entered into a scatter plot in figure $2.5 \mathrm{c}$ that shows the dependent variable in a normal P-P plot of the regression standardized residuals. The observed cumulative residuals are plotted against the expected cumulative residuals and it can be seen that the residuals are normally distributed as the points tend to lie on a straight line and the normal distribution assumption is not violated.

\subsubsection{Linearity}

For the linearity assumption to be met the values of the outcome variable for each increment of the predictor(s) must lie along a straight line as seen in figure $2.5 \mathrm{c}$. The scatter plot in figure $2.5 \mathrm{a}$ and $2.5 \mathrm{~b}$ further lend support to this assumption as they display no clear pattern and the residuals appear to be dispersed around the reference line. Hence, the model appears to meet the criteria of linearity.

\subsubsection{Scale reliability}

Cronbach's Alpha will help determine the reliability. The overall, Cronbach's Alpha for the Model is $.817(\alpha=.817)$ which can be regarded as acceptable.

\subsubsection{Descriptive statistics of the survey data}

Table 2.4 Means and standard deviations of test variable

\section{Descriptive Statistics}

\begin{tabular}{llll}
\hline & Mean & Std. Deviation & $\mathrm{N}$ \\
\hline SMISSTATUS & 3.0000 & 1.11524 & 21 \\
\hline SYSPERSPECTIVE & 2.0649 & .84119 & 21 \\
\hline TECHMED & 2.8701 & 1.26080 & 21 \\
\hline
\end{tabular}

The table 2.4 above shows the mean and standard deviation for each variable included in the regression analysis. The means of the independent and dependent variable were found to be approximately 3,2 and 3 respectively, implying that there could be some relationship between the independent and dependent variables worth investigating. This would be helpful to prove the developed evaluation model for SMIS.

\subsubsection{Correlations}

The correlation coefficients for each path, that is, the links between each of the variables should be statistically significant $(\mathrm{p} \leq 0.05$. The correlations between the independent variables should not be too high. ( 0.8 upwards usually create issues of multicollinearity).

Table 2.5 Correlations 


\begin{tabular}{lllll}
\hline Correlations & \multicolumn{3}{c}{} & \\
\hline & & SMISSTATUS & SYSPERSPECTIVE & TECHMED \\
\hline Pearson Correlation & SMISSTATUS & 1.000 & .752 & .933 \\
\cline { 2 - 5 } & SYSPERSPECTIVE & .752 & 1.000 & .703 \\
\cline { 2 - 5 } & TECHMED & .933 & .703 & 1.000 \\
\hline Sig. (1-tailed) & SMISSTATUS &. & .004 & .000 \\
\cline { 2 - 5 } & SYSPERSPECTIVE & .004 &. & .006 \\
\cline { 2 - 5 } & TECHMED & .000 & .006 & 21 \\
\hline $\mathrm{N}$ & SMISSTATUS & 21 & 21 & 21 \\
\cline { 2 - 5 } & SYSPERSPECTIVE & 21 & 21 & 21 \\
\cline { 2 - 5 } & TECHMED & 21 & & 21 \\
\hline
\end{tabular}

The Table 2.5 above reveal a significant correlation between the dependent variable SMISSTATUS and the two independent variables; SYSPERSPECTIVE and TECHMMED; $R=.752$ and .933 respectively with $\mathrm{p}<0.05$. There does not seem to exist a particularly strong association between SYSPERSPECTIVE and their TECHMED, $(\mathrm{R}=0.703)$ that may be sufficiently large to cause problems of multicollinearity in subsequent stages of the analysis. These results indicate that, at the bivariate level, each of the conditions necessary for the multiple regression analysis has been met.

\subsubsection{Multiple Regression Analysis}

Table 2.6 Summary of the model relationship

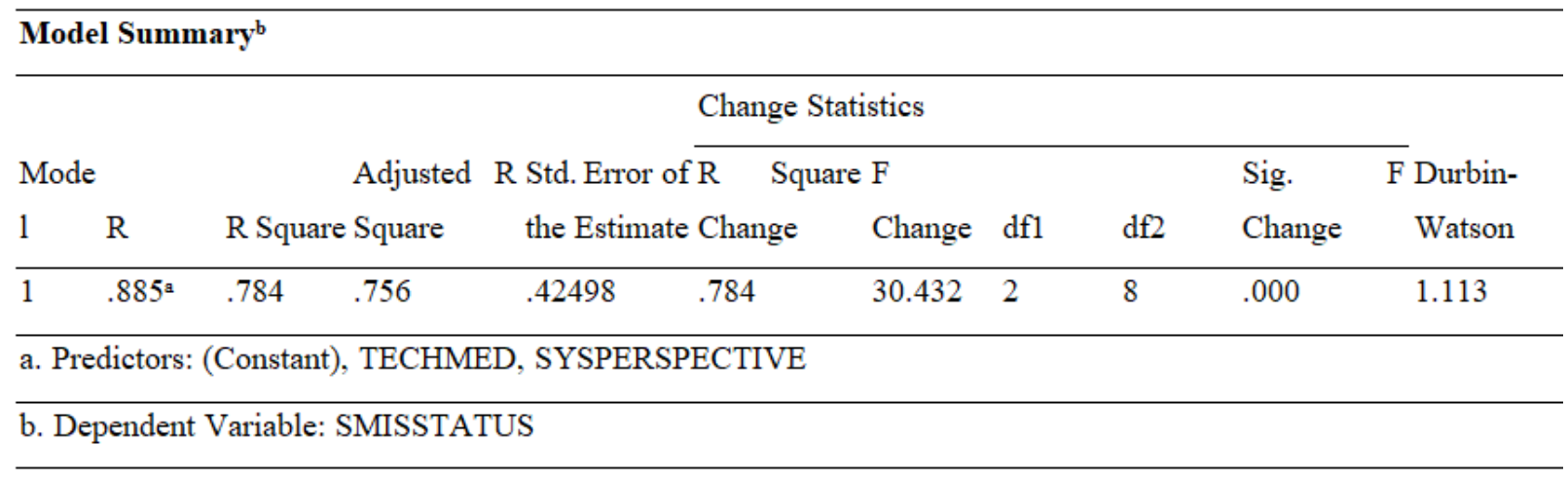


The model summary in table 2.6 shows that $78 \%$ of all responses on SMISSTATUS can be explained by the responses on SYSPERSPECTIVE and TECHMED at 95\% confidence level $(\mathrm{p}<0.05)$ indicating that SYSPERSPECTIVE and TECHMED determined the SMISSTATUS indicating the significant relationship between SYSPERSPECTIVE and TECHMED and SMISSTATUS.

Furthermore the $R^{2}$ value $=.78$, which indicates that $78 \%$ of the changes in SMISSTATUS can be explained by the independent variables. The adjusted $R^{2}$ at .756 is inherently lower as it accounts for other possible indicators. Overally, taking into account the adjusted $R^{2}, 88 \%$ of the variation in SMISSTATUS can be explained with the use of the model.

Table 2.7 Regression values from ANOVA.

\begin{tabular}{|c|c|c|c|c|c|c|}
\hline Model & & $\begin{array}{l}\text { Sum } \\
\text { Squares }\end{array}$ & of ${ }_{\text {Df }}$ & Mean Square & $\mathrm{F}$ & Sig. \\
\hline \multirow[t]{3}{*}{1} & Regression & 10.993 & 2 & 5.496 & 30.432 & $.000^{\mathrm{a}}$ \\
\hline & Residual & 3.432 & 19 & .181 & & \\
\hline & Total & 14.425 & 21 & & & \\
\hline
\end{tabular}

The $F$-ratio in the ANOVA table 2.7 above tests whether the overall regression model is a good fit for the data. The table shows that the independent variables statistically significantly predict the dependent variable, $F(2,21)=30.432, p<.0005$ (i.e., the regression model is a good fit of the data). 
Table 2.8 Model coefficients and collinearity statistics.

\begin{tabular}{|c|c|c|c|c|c|c|c|c|}
\hline \multirow[b]{3}{*}{ Model } & & \multirow{2}{*}{\multicolumn{2}{|c|}{$\begin{array}{l}\text { Unstandardized } \\
\text { Coefficients }\end{array}$}} & \multirow{3}{*}{$\begin{array}{l}\text { Standardized } \\
\text { Coefficients }\end{array}$} & \multirow[b]{3}{*}{$\mathrm{T}$} & \multirow[b]{3}{*}{ Sig. } & \multirow{2}{*}{\multicolumn{2}{|c|}{$\begin{array}{l}\text { Collinearity } \\
\text { Statistics }\end{array}$}} \\
\hline & & & & & & & & \\
\hline & & B & Std. Error & & & & Tolerance & VIF \\
\hline \multirow[t]{4}{*}{1} & (Constant) & .484 & .367 & & 1.318 & .224 & & \\
\hline & SYSPERSPECTI & .215 & .231 & .162 & .928 & .038 & .478 & 2.093 \\
\hline & VE & & & & & & & \\
\hline & TECHMED & .722 & .154 & .816 & 4.683 & .002 & .478 & 2.093 \\
\hline
\end{tabular}

The Unstandardized coefficients indicate how much the dependent variable varies with an independent variable when all other independent variables are held constant. The table 2.8 above illustrates that $b_{0}=0.484$, and hence the model predicts a SMISSTATUS score of .484 if the values of predictor variables is set to 0. Additionally, $b_{1}$ SYSPERSPECTIVE is 0.215 with a significance of .038 . b2, the coefficient for TECHMED is 0.722 with a significance of .002 seems to be a better predictor for SMISSTATUS. Therefore the two predictors are useful in predicting the status of SMIS and the model is usable in SMIS evaluation.

The model equation becomes;

\section{SMISSTATUS $=0.484+0.215($ SYSPERSPECTIVE $)+0.722($ TECHMED $)+$ error term}

The statistical significance of each of the independent variables is found by testing whether the unstandardized (or standardized) coefficients are equal to 0 (zero) in the population. If $p<.05$, we can conclude that the coefficients are statistically significantly different to 0 (zero). The $t$-value and corresponding $p$-value are located in the " $t$ " and "Sig." columns, respectively in the table 2.8 above confirm the statistical significance of independent variables ( $\mathrm{Sig}<0.05$ in both cases). Although the intercept, $\mathrm{b}_{0}$, is tested for statistical significance, this is rarely an important or interesting finding.

We, therefore, conclude that a multiple regression was run to predict SMISSTATUS from SYSPERSPECTIVE and TECHMED. These variables statistically significantly predicted SMISSTATUS, $F(2,21)=30.432, p<.0005, R^{2}=.884$. The two independent variables added statistically significantly to the prediction, $p<.05$. The model is therefore; fit to be used to predict the status of schools' management information systems (SMIS) given the system perspectives and technical mediation observations.

\section{REFERENCES}

[1] Artit K. (2012) Management Information System Implementation Challenges, Success Key Issues, Effects and Consequences: A Case Study of Fenix System, Jönköping University

[2] Breiter, A., \& Light, D. (2006). Data for school improvement: Factors for designing effective information systems to support decision making in schools. Educational Technology \& Society. Retrieved July 26, 2010, from http://www.ifets.info/journals/9_3/18.pdf

[3] Chen, H.T. (2015). Practical program evaluation: Theory-Driven Evaluation and the Integrated Evaluation Perspective. Thousand Oaks, CA: Sage.

[4] Chen, H.-T. (2005). Practical program evaluation. Assessing and improving planning, implementation, and effectiveness. Thousand Oaks, CA: Sage.

[5] Chen, H.-T. (1994). Theory-driven evaluations: Needs, difficulties, and options. Evaluation Practice, 15, 79-82.

[6] Curry, H. (2004). The current battle damage assessment paradigm is obsolete. Air and Space Power Journal, 18, 13-17.

[7] Demir, K. (2003). İl milli eğitim müdürlüğü yönetim bilgi sistemlerinin değerlendirilmesi. Eğitim Yönetimi, 9(36), 558-581.

[8] Donaldson, S. I. (2007). Program theory-driven evaluation science: Strategies and applications. New York, NY: Taylor and Francis.

[9] Dyczkowski, M. (2007). Skuteczność wdrażania gospodarczych systemów informacyjnychw świetle badań ankietowych. In Chmielarz W., Parys T. (Ed.), Zastosowania systemów ebiznesuw gospodarce, Warsaw, Poland: Wydawnictwo Wyższej Szkoły Ekonomiczno-Informatycznej.

[10] Ein-dor, P. \& Segev, E. (1978) Organizational context and the success of management information systems. Management Science, 24 (10), $1064-1077$.

[11] English, B., \& Kaleveld, L. (2003). The politics of program logic. Evaluation Journal of Australasia, 3, 35-42

[12] Fetterman, D.M. (2012). Empowerment Evaluation: Learning to think like an evaluator. In M.C. Alkin (Ed.), Evaluation Roots (2nd edition) (pp. 304-322).

[13] Greene, J.C., Boyce, A.S, \& Ahn, J. (2011). Value-Engaged, Educative Evaluation Guidebook. University of Illinois, Urbana-Champaign.

[14] Kumar, A. \& Malik, P. (2011). Critical Success Factors in ERP Implementation in India. International Transactions in Applied Sciences, 4 (2), pp. $271-280$.

[15] Laudon, K. \& Laudon, J. (2006) Management Information Systems: Managing the Digital Firm, 9th ed. Prentice Hall: New Jersey

[16] Laudon, K. \& Laudon, J. (2014) Management Information Systems: Managing the Digital Firm, 13th ed. Prentice Hall: New Jersey

[17] Lipsey, M. W., Crosse, S., Dunkle, J., Pollard, J., \& Stobart, G. (1985). Evaluation: The state of the art and the sorry state of the science. In Cordray. D. S (Ed.), Utilizing prior research in evaluation planning (pp. 7-28). New Directions for Program Evaluation, Vol. 27. San Francisco: Jossey-Bass.

[18] McLeod, L. \& MacDonell, S. G. (2011). Factors that Affect Software Systems DevelopmentProject Outcomes: A Survey of Research. ACM Computing Surveys, 43(4), pp. 24.1-24.56.

[19] Murthy, C. S. V. (2006) Management information systems. Mumbai, Himalaya Publishing House.

[20] Ofunoye, C.M. Innovation and Resilience of Small-Medium Entrepreneurs in Port Harcourt. Sch. J. Sci. Res. Essay 2017, 6, 61-66. 
[21] Olawale Fatoki ( 2018) in his study on The Impact of Entrepreneurial Resilience on the Success of Small and Medium Enterprises in South Africa," Sustainability, MDPI, Open Access Journal, vol. 10(7), pages 1-12, July.

[22] Omwenga E.I \& Rodrigues A.J. (2006). Towards an Education Evaluation Framework: Synchronous and Asynchronous E-learning Cases. Journal of the Research Centre for Educational Technology Spring 2006. http://www.rcet.org

[23] Oyier, R. C., \& Mwanda, S. O. (2011). Impact of information and communication technology in the management of private secondary schools in Nairobi Kenya. Retrieved November 18, 2012, from University of Nairobi: www.uonbi.ac.ke/faculties/turntopdf.php?project_id=1344

[24] Patton, M.Q. (2013). Utilization-Focused Evaluation (U-FE) Checklist. Western Michigan University Checklists.

[25] Pelgrum, W.J. (2001). Obstacles to the integration of ICT in education: results from a worldwide educational assessment. Computers \& Education $37,163-178$.

[26] Posavac, E.J., \& Carey, R. G. (2006). Program evaluation: Methods and case studies (7th ed.). Upper Saddle River, NJ: Pearson.

[27] Rauch, J. T. (2002). Assessing airpower's effects: Capabilities and limitations of real-time battle damage assessment. (Masters dissertation, School of Advanced Airpower, Air University, 2002). Retrieved September 10, 2018, from http://handle.dtic.mil/100.2/ADA420587.

[28] Rogers, P. J. (2007). Theory-based evaluation: Reflection ten years on. In Mathison, S. (Ed.), Enduring issues in evaluation: The 20th anniversary of the collaboration between NDE and AEA. New Directions for Evaluation, Vol. 114. San Francisco: Jossey Bass.

[29] Rogers, P. J. (2000). Programtheory: Not whether programs work but how they work. In

[30] Stufflebeam. D. L,Madaus. G. F, \& Kellaghan. T (Eds.), Evaluation models (pp. 209-232). Boston: Kluwer Academic.

[31] Scriven, M. (1994). The fine line between evaluation and explanation. Evaluation Practice, 15, 75-77.

[32] Shadish, W. R. Jr., Cook, T. D., \& Leviton, L. C. (1991). Chapter 2: Good theory for social program evaluation. Foundations of Program Evaluation: Theories of Practice (pp. 36-67). Newbury Park, CA: Sage.

[33] Shaw, I., \& Crompton, A. (2003). Theory, like mist on spectacles, obscures vision. Evaluation, 9, 192-204.

[34] Stufflebeam, D. L. (Ed.). (2001). Evaluation models. New directions for evaluation, 89. San Francisco: Jossey-Bass.

[35] Sullivan, H. \& Stewart, M. (2006). Who owns the theory of change? Evaluation, 12, 179-199.

[36] Tripathi, K. P. (2011) Role of management information system (MIS) in human resource. International Journal of Computer Science and Technology, 2 (1), 58-62.

[37] Webber, C.F. (2003). New technologies and educative leadership. Journal of Educational Administration, 41(2), 119-123.

[38] Weiss, C. H. (1997a). How can theory-based evaluations make greater headway? Evaluation Review, 21, 501-524.

[39] Yuen, A.H.K.; Law, N; Wong, K.C. (2003). ICT implementation and school leadership: Case studies of ICT integration in teaching and learning. Journal of Educational Administration, 41(2), 158-170.

\section{AUTHORS}

First Author - Bernard Okeyo Amollo(amolohb@gmail.com, Jaramogi Oginga Odinga University of Science and Technology-Kenya Second Author - Dr. Joshua Agola(agolaus@ gmail.com, Jaramogi Oginga Odinga University of Science and Technology-Kenya Third Author - Prof. Antony Rodrigues (tonyaniceto@gmail.com, Jaramogi Oginga Odinga University of Science and TechnologyKenya 